\title{
Involvement of a Multidrug Efflux Pump and Alterations in Cell Surface Structure in the Synergistic Antifungal Activity of Nagilactone E and Anethole against Budding Yeast Saccharomyces cerevisiae
}

\author{
Yuki Ueda ${ }^{1}$, Yuhei O. Tahara ${ }^{1}$, Makoto Miyata ${ }^{1} \mathbb{C}$, Akira Ogita ${ }^{1,2}$, Yoshihiro Yamaguchi ${ }^{1}$, Toshio Tanaka ${ }^{1}$ \\ and Ken-ichi Fujita 1,*(D) \\ 1 Graduate School of Science, Osaka City University, Sumiyoshi-ku, Osaka 558-8585, Japan; \\ g38dw2nop@gmail.com (Y.U.); taharayuhei@osaka-cu.ac.jp (Y.O.T.); miyata@osaka-cu.ac.jp (M.M.); \\ ogita@osaka-cu.ac.jp (A.O.); yyamaguchi@osaka-cu.ac.jp (Y.Y.); seitaiteibunshi_labo@yahoo.co.jp (T.T.) \\ 2 Research Center for Urban Health and Sports, Osaka City University, Sumiyoshi-ku, Osaka 558-8585, Japan \\ * Correspondence: kfujita@osaka-cu.ac.jp; Tel.: +81-6-6605-2580
}

check for

updates

Citation: Ueda, Y.; Tahara, Y.O.; Miyata, M.; Ogita, A.; Yamaguchi, Y.; Tanaka, T.; Fujita, K.-i. Involvement of a Multidrug Efflux Pump and Alterations in Cell Surface Structure in the Synergistic Antifungal Activity of Nagilactone E and Anethole against Budding Yeast Saccharomyces cerevisiae. Antibiotics 2021, 10, 537. https://doi.org/10.3390/ antibiotics 10050537

Academic Editors:

Constantinos Athanassopoulos,

Carlos L. Cespedes Acuña and María Cecilia Carpinella

Received: 15 April 2021

Accepted: 3 May 2021

Published: 6 May 2021

Publisher's Note: MDPI stays neutral with regard to jurisdictional claims in published maps and institutional affiliations.

\begin{abstract}
Nagilactone E, an antifungal agent derived from the root bark of Podocarpus nagi, inhibits $1,3-\beta$ glucan synthesis; however, its inhibitory activity is weak. Anethole, the principal component of anise oil, enhances the antifungal activity of nagilactone E. We aimed to determine the combinatorial effect and underlying mechanisms of action of nagilactone $\mathrm{E}$ and anethole against the budding yeast Saccharomyces cerevisiae. Analyses using gene-deficient strains showed that the multidrug efflux pump PDR5 is associated with nagilactone E resistance; its transcription was gradually restricted in cells treated with the drug combination for a prolonged duration but not in nagilactone-E-treated cells. Green-fluorescent-protein-tagged Pdr5p was intensively expressed and localized on the plasma membrane of nagilactone-E-treated cells but not in drug-combination-treated cells. Quick-freeze deep-etch electron microscopy revealed the smoothening of intertwined fiber structures on the cell surface of drug-combination-treated cells and spheroplasts, indicating a decline in cell wall components and loss of cell wall strength. Anethole enhanced the antifungal activity of nagilactone E by enabling its retention within cells, thereby accelerating cell wall damage. The combination of nagilactone $\mathrm{E}$ and anethole can be employed in clinical settings as an antifungal, as well as a food preservative to restrict food spoilage.
\end{abstract}

Keywords: antifungal; nagilactone E; drug resistance; multidrug efflux pump; quick-freeze deep-etch electron microscopy

\section{Introduction}

Antibiotics and preservatives used in food items should have minimal side effects in humans and specifically target microbes. Fungi, including molds and yeasts, are eukaryotes and have metabolic processes and cell structures similar to those of humans, which makes the development of targeted treatment options against fungal pathogens a challenge. In addition, the emergence of drug-resistant fungi in recent years has become a serious problem for effective chemotherapy against deep-seated mycoses [1]. Therefore, drug-resistant fungi need to be controlled using new drugs or combination therapy. In combination therapy, resistance of fungal cells to a drug can be overcome using another drug that suppresses this resistance.

Nagilactones are norditerpene dilactones isolated from the root bark of Podocarpus nagi [2]. Nagilactone C, D, and F have insect feeding deterrent activity against Lactuca sativa [3]. Nagilactone $C$ has insecticidal activity against Musca domestica Linnaeus [4] and potent antitumor activity against Yoshida sarcoma [5,6]. Nagilactone D and E (nagilactone E; Figure 1) inhibit seed germination in Lactuca sativa [7]. In addition, nagilactone E exhibits antifungal activity 
against Candida albicans, Pityrosporium ovale, and the budding yeast Saccharomyces cerevisiae [8]. The activity of nagilactone E against $S$. cerevisiae depends on inhibition of $1,3-\beta$ glucan synthase [9]. As the activity is relatively weaker than that of other available antifungal drugs, such as micafungin and fluconazole [10], other drugs can be used in combination with nagilactone E to enhance its antifungal activity.<smiles></smiles>

Nagilactone E<smiles>C/C=C/c1ccc(OC)cc1</smiles>

trans-Anethole

Figure 1. Chemical structures of nagilactone E and trans-anethole.

Anethole, a phenylpropanoid (Figure 1), is a major compound present in anise and fennel oils and exhibits antifungal activity against various fungi, including $S$. cerevisiae and C. albicans [8,11-13]. It alters the morphology of the filamentous fungus Mucor mucedo by inhibiting hyphal growth and the cell wall biosynthetic enzyme, chitin synthase [13]. In addition, it induces the production of reactive oxygen species and DNA fragmentation and induces apoptotic-like cell death in S. cerevisiae and Aspergillus fumigatus [14]. However, the antifungal activity of anethole, similar to nagilactone $E$, is relatively weaker than that of drugs available in the market [13].

Anethole enhances the antifungal activity of $n$-dodecanol, $(E)$-2-undecenal, polygodial, and nagilactone $\mathrm{E}$ in $S$. cerevisiae and C. albicans $[8,15,16]$. The antifungal effect of the model antifungal drug dodecanol against $S$. cerevisiae reduces with prolonged incubation because of the drug efflux activity of Pdr5p, a multidrug ATP-binding cassette (ABC) transporter $[15,17,18]$. Anethole suppresses PDR5 transcription, thereby synergistically enhancing the antifungal activity of dodecanol $[17,18]$.

In this study, we elucidated the genetic basis of the synergistic antifungal activity of nagilactone $\mathrm{E}$ and anethole against $S$. cerevisiae using deletion mutants. The effects of the combination of drugs on the yeast cell wall were determined using fluorescence and electron microscopy. Our results would benefit the practical application of nagilactone $\mathrm{E}$ as an antifungal agent.

\section{Results}

\subsection{Antifungal Activity of Nagilactone E, Aenethole, and Their Combination}

The minimum inhibitory concentration (MIC) assay was performed using the broth dilution method. The MIC values of nagilactone E, anethole, and their combination against S. cerevisiae and C. albicans, including fluconazole-resistant strains, are summarized in Table 1. The fractional inhibitory concentration (FIC) indices of drug combinations are also indicated. Because of the limited solubility of nagilactone $\mathrm{E}$ in $N, N$-dimethylformamide (DMF), a final concentration of more than $2000 \mu \mathrm{M}$ was not tested. The MIC values of nagilactone $\mathrm{E}$ and anethole for $S$. cerevisiae after $72 \mathrm{~h}$ of incubation were 500 and $2500 \mu \mathrm{M}$, respectively. The FIC index of the drug combination was 0.3125 , indicating a synergistic effect. The FIC indices for all C. albicans strains were less than 0.5625 , indicating weak synergistic effects. These results suggest that fluconazole resistance does not affect the synergistic antifungal activity of the drug combination. 
Table 1. MICs of nagilactone E, anethole, or their combination against S. cerevisiae or C. albicans.

\begin{tabular}{|c|c|c|c|c|}
\hline \multirow{2}{*}{\multicolumn{2}{|c|}{ Strain }} & \multicolumn{2}{|c|}{$\operatorname{MIC}^{a}(\mu \mathrm{M})$ at $72 \mathrm{~h}$} & \multirow{2}{*}{ FIC $^{b}$ Index } \\
\hline & & Nagilactone E & Anethole & \\
\hline \multirow{3}{*}{$\begin{array}{c}\text { S. cerevisiae } \\
\text { BY4741 }\end{array}$} & $\Delta 1$ & 500 & - & - \\
\hline & Alone & - & 2500 & - \\
\hline & Combination & 31.3 & 625 & 0.31 \\
\hline \multirow{3}{*}{$\begin{array}{l}\text { C. albicans } \\
\text { NBRC1061 }\end{array}$} & & 1000 & - & - \\
\hline & Alone & - & 1250 & - \\
\hline & Combination & 62.5 & 625 & 0.56 \\
\hline \multirow{3}{*}{$\begin{array}{l}\text { C. albicans } \\
{\text { IFM } 46910^{c}}^{\text {c }}\end{array}$} & & $>1000$ & - & - \\
\hline & Alone & - & 1250 & - \\
\hline & Combination & 250 & 313 & $<0.5$ \\
\hline \multirow{3}{*}{$\begin{array}{l}\text { C. albicans } \\
{\text { IFM } 54354^{c}}^{c}\end{array}$} & & $>1000$ & - & - \\
\hline & Alone & - & 1250 & - \\
\hline & Combination & 62.5 & 625 & $<0.56$ \\
\hline
\end{tabular}

${ }^{a}$ Minimum inhibitory concentration. ${ }^{\mathrm{b}}$ Fractional inhibitory concentration. The FIC index for the drug combination was calculated as (MICa combination/MICa alone) + (MICb combination/MICb alone), where a and $\mathrm{b}$ are the two compounds tested. The FIC index values are significant values obtained from the checkerboard matrix. FIC indices were used to define the interaction of combined compounds: synergistic $(X<0.5)$, additive $(0.5<X<1)$, indifferent $(1<X<4)$, or antagonistic $(X>4)$. ${ }^{\mathrm{c}}$ Fluconazole-resistant strains.

The cell viability of S. cerevisiae in the presence of nagilactone E, anethole, and their combination was determined using the number of colony-forming units (CFUs) (Figure 2). Anethole $(312.5 \mu \mathrm{M})$ did not affect cell viability. Although nagilactone E $(250 \mu \mathrm{M})$ reduced cell viability within $48 \mathrm{~h}$ of incubation, cell viability recovered by $72 \mathrm{~h}$. In contrast, when anethole and nagilactone $\mathrm{E}$ were used in combination, the decrease in cell viability continued until $72 \mathrm{~h}$. To summarize the above results, anethole extended the fungicidal activity of nagilactone E. Anethole showed synergy with the surfactant dodecanol (log of partition coefficient: $\log \mathrm{P}=4.31$ ) via the inhibition of drug efflux [18]. Nagilactone $\mathrm{E}$ is also an amphiphilic substance $(\log \mathrm{P}=1.26, \log \mathrm{P}=1.39$ for $n$-pentanol). Thus, the drug may be continually transported out of the cell by multidrug $\mathrm{ABC}$ transporters located on the cell membrane. In addition, anethole possibly inhibits nagilactone $\mathrm{E}$ drug efflux, thereby sustaining its antifungal activity.

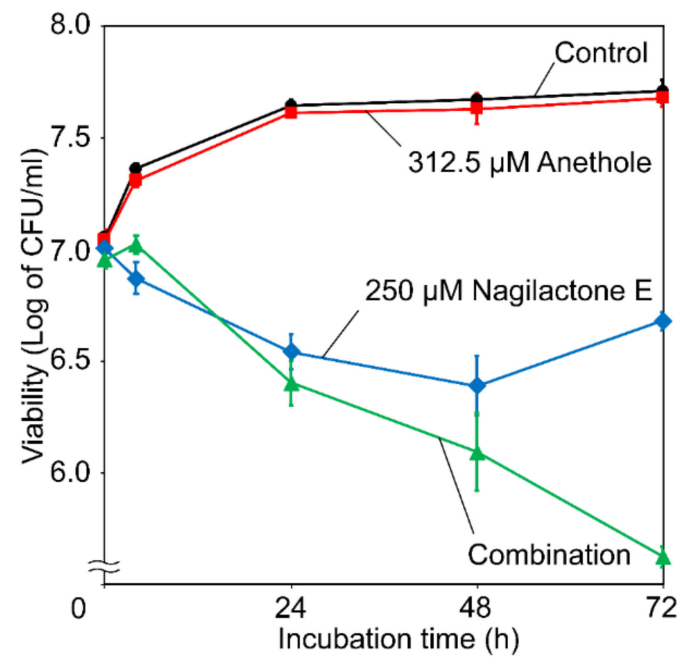

Figure 2. Cell viability in the presence of anethole, nagilactone E, or their combination. Exponentially growing cells of S. cerevisiae BY 4741 at $30^{\circ} \mathrm{C}$ in YPD medium supplemented with $312.5 \mu \mathrm{M}$ anethole (ם), $250 \mu \mathrm{M}$ nagilactone $\mathrm{E}(\bullet)$, or $312.5 \mu \mathrm{M}$ anethole $+250 \mu \mathrm{M}$ nagilactone $\mathrm{E}(\boldsymbol{\Delta})$. Closed circles $(\bullet)$ denote controls (treatment without drugs). Data are expressed as the mean \pm standard deviation $(n=3)$. 


\subsection{Identification of Genes Associated with Nagilactone-Efflux Using Gene-Deficient Strains}

To identify the genes associated with multidrug resistance and susceptibility to nagilactone $\mathrm{E}$, we evaluated the susceptibilities of single gene-deficient, double gene-deficient pdr1 $\Delta$ pdr3 $\Delta$ (BY25929), and 13 multi-gene-deficient (dTC063) strains and their parental BY4741 strains. After $72 \mathrm{~h}$ of incubation with nagilactone E, the cell turbidity of pdr5 $\Delta$, BY25929, and dTC063 cells was analyzed by absorbance measurements at $600 \mathrm{~nm}$. The absorbance value was found to be less than 1.0, which was the adjusted value at the beginning of incubation (Figure 3). These results indicated that these three mutants are highly sensitive to nagilactone $\mathrm{E}$. In addition, a decrease in cell turbidity indicated nagilactone-Einduced cell lysis. Cell lysis may be the result of a fragile cell wall due to the inhibition of $\beta$-glucan biosynthesis [9]. Moreover, nagilactone E was potentially effluxed by Pdr5p, as are amphiphilic and lipophilic xenobiotic compounds, including antibiotics [19]. Although double gene-deficient $p d r 1 \Delta p d r 3 \Delta$ strains were susceptible to nagilactone $\mathrm{E}$, single genedeficient $p d r 1 \Delta$ or $p d r 3 \Delta$ strains were not. PDR1 and PDR3 are reported to be transcription factors required for $P D R 5$ transcription [20]. These results indirectly indicate that both $p d r 1$ and $p d r 3$ are required for the activation of PDR 5 transcription. Based on these results, we speculated that Pdr5p is an important multidrug efflux pump associated with the combinatorial antifungal activity of nagilactone $\mathrm{E}$ and anethole.

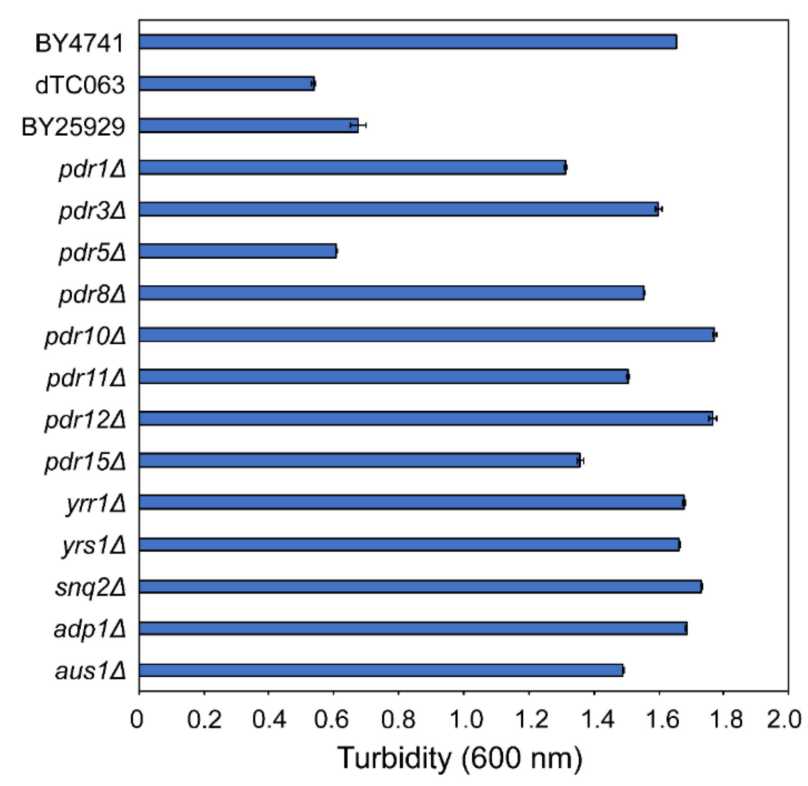

Figure 3. Susceptibility to nagilactone $\mathrm{E}$ in S. cerevisiae mutants lacking genes associated with multidrug resistance. BY4741, dTC063, and BY25929 are parental, 13 multi-gene-deficient, and double genedeficient $(p d r 1 \Delta p d r 3 \Delta)$ strains, respectively. Exponentially growing cells were grown at $30{ }^{\circ} \mathrm{C}$ with $72 \mathrm{~h}$ shaking in $2.5 \% \mathrm{ME}$ with $250 \mu \mathrm{M}$ nagilactone $\mathrm{E}$. Data are expressed as the mean \pm standard deviation $(n=3)$.

\subsection{Effects of Anethole, Nagilactone E, and Their Combination on PDR5 Transcription}

The transcript levels of PDR5 may potentially influence nagilactone E efflux. To determine the effect of anethole on PDR5 transcription in cells treated with nagilactone $\mathrm{E}$, transcription levels of $P D R 5$ were quantified using reverse transcription quantitative polymerase chain reaction (RT-qPCR). Their transcription levels were normalized to 1.0 against transcript levels of the housekeeping gene ACT1. The levels were significantly higher in nagilactone-E-treated cells than those in untreated or anethole-treated cells. Interestingly, in the cells treated with the combination of drugs, the PDR5 transcript level was more than 4 -fold higher than that in the nagilactone-E-treated cells at $4 \mathrm{~h}$ after treatment. However, as incubation with the drugs continued, the level decreased gradually and finally reached almost the same level as that in untreated cells (Figure 4). These results indicated the possibility that 
when PDR5 transcription is intensively induced by the drug combination, it is subsequently suppressed by anethole. In the drug-combination-treated cells, PDR5 transcription was upregulated, especially at 4 and $24 \mathrm{~h}$ incubations, and was possibly translated to large amounts of Pdr5p. However, it is to be noted that transcription levels do not necessarily reflect the protein levels.

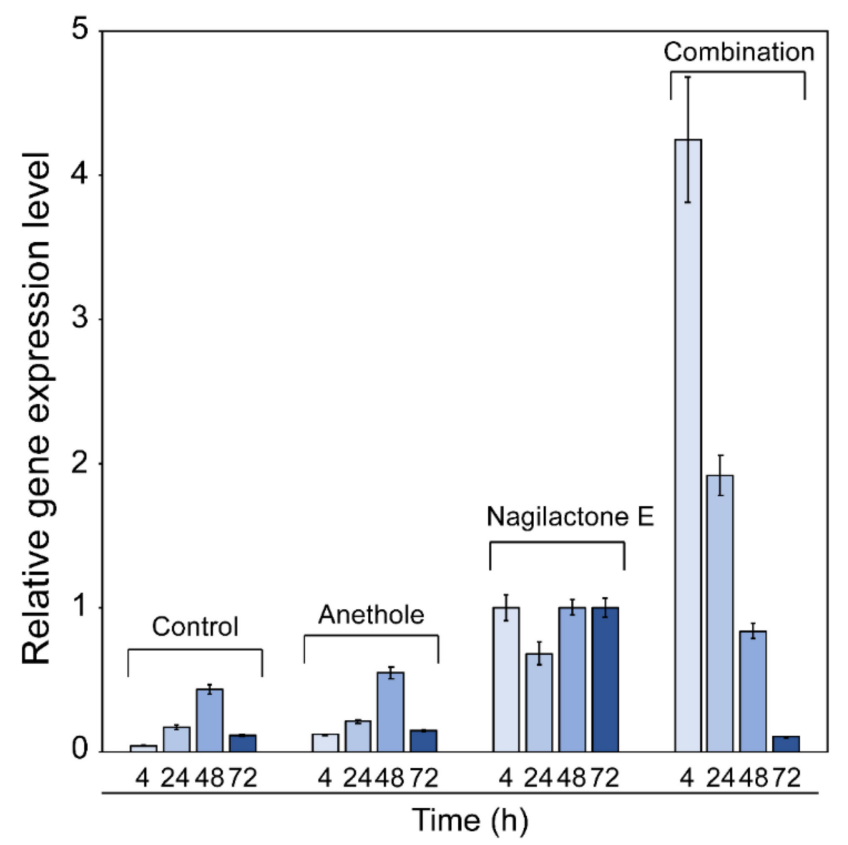

Figure 4. Relative gene expression of PDR5 in S. cerevisiae BY4741. Exponentially growing cells were grown at $30{ }^{\circ} \mathrm{C}$ in $2.5 \% \mathrm{ME}$ treated with $312.5 \mu \mathrm{M}$ anethole, $250 \mu \mathrm{M}$ nagilactone $\mathrm{E}$, or their combination. Control denotes treatment without drugs. Total RNA was then extracted and analyzed by RT-qPCR. Gene expression is shown relative to ACT1 expression. Data are expressed as the mean \pm standard deviation $(n=3)$.

\subsection{Visualization of Green Fluorescent Protein (GFP)-Tagged Pdr5p}

To analyze Pdr5p protein levels in cells treated with nagilactone E, anethole, and their combination, we tagged Pdr5p with GFP at the C-terminus. The strain harboring GFP-tagged Pdr5p showed the same susceptibility toward the drugs as the parental BY4741 strain. No fluorescence was detected in the cytoplasm or vacuoles of the control cells treated with DMF. A slight fluorescence was detected in the anethole-treated cells (Figure 5). Strong fluorescence was detected on the membranes, especially plasma membranes, in nagilactone-E-treated cells only at $72 \mathrm{~h}$ (Figure 5). These results indicated that Pdr5p translation is induced in the presence of nagilactone $\mathrm{E}$ after $48 \mathrm{~h}$ of incubation. In contrast, almost no fluorescence was observed in cells treated with the drug combination throughout incubation. Therefore, anethole or nagilactone E probably restricted Pdr5p expression at the translational level. 


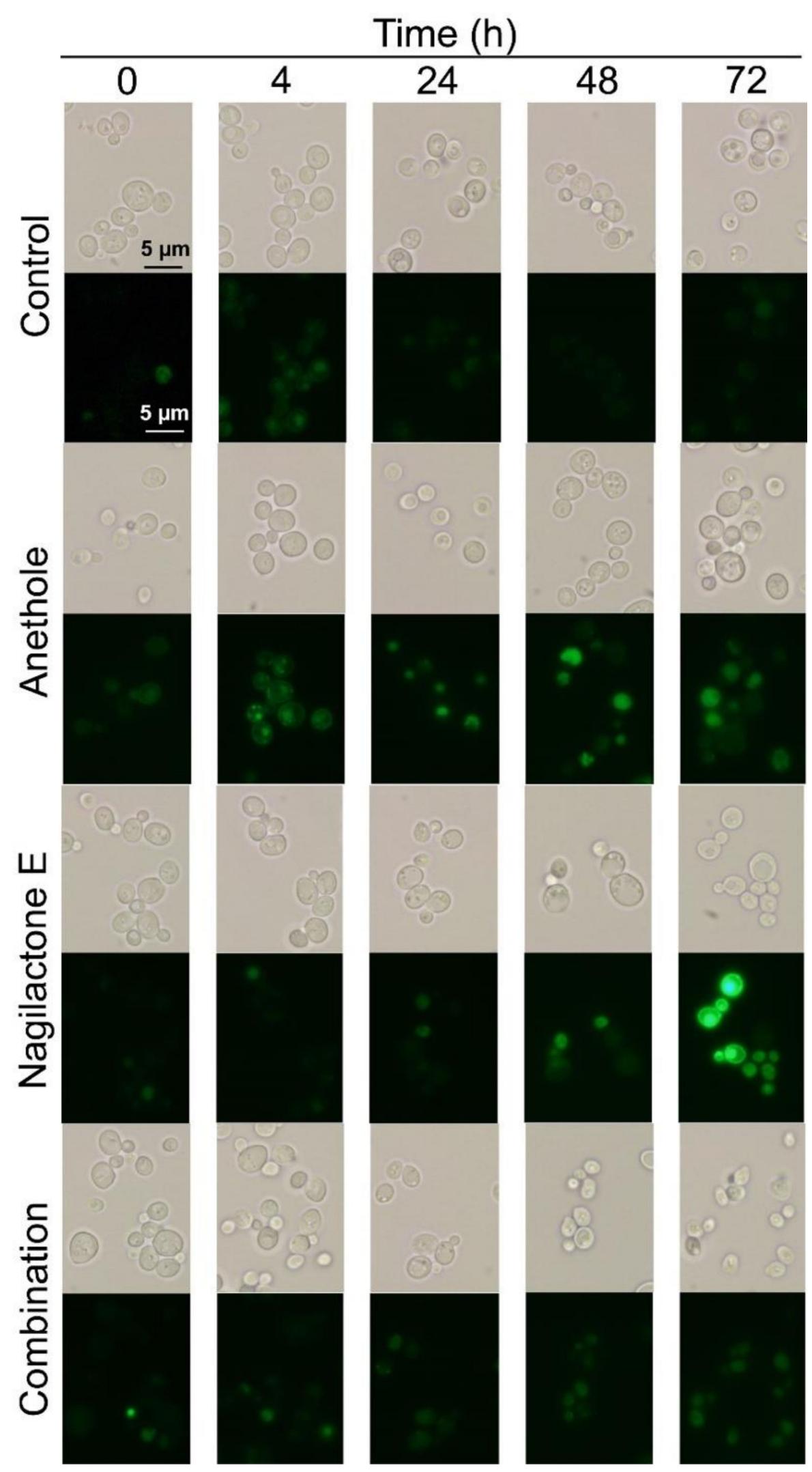

Figure 5. Phase-contrast and fluorescent micrographs of cells expressing Pdr5p tagged with green fluorescent protein. Exponentially growing cells were grown at $30{ }^{\circ} \mathrm{C}$ in $2.5 \% \mathrm{ME}$ treated with $312.5 \mu \mathrm{M}$ anethole, $250 \mu \mathrm{M}$ nagilactone $\mathrm{E}$, or their combination. Control denotes treatment without drugs. Refer to Supplementary Figure S1 for the original uncropped photos of cells after $72 \mathrm{~h}$ of incubation with and without drugs. 
In the time-kill assay (Figure 2), the viability of nagilactone-E-treated cells was recovered after $48 \mathrm{~h}$ of incubation, whereas a gradual decrease in the viability of drugcombination-treated cells was observed. This difference is probably because of an increase in Pdr5p levels after $48 \mathrm{~h}$ of incubation. In other words, an increase in Pdr5p levels caused by nagilactone E accumulation in the cells takes at least $48 \mathrm{~h}$.

\subsection{Visualization of $\beta$-Glucan and Mannan on the Cell Surface}

Nagilactone E weakly inhibits $\beta$-glucan synthase and then causes a slight fragility in the fungal cell wall [9]. To determine whether anethole accelerates the inhibitory effect of nagilactone $\mathrm{E}$, the cell wall components of treated and untreated cells were visualized by staining with aniline blue or fluorescently labeled ConA (FITC-ConA). Aniline blue and FITC-ConA are usually used to stain $\beta$-glucan and mannan present in the cell wall, respectively [21]. In the spheroplasts treated with zymolyase, no fluorescence was detected, indicating a lack of $\beta$-glucan (Supplementary Figure S2B). In contrast, fluorescence was observed around the cell circumference in all the cells treated with nagilactone $\mathrm{E}$ and/or anethole (Supplementary Figure S2A,D). These results indicated that nagilactone $E$ and anethole target $\beta$-glucan and mannan in the cell wall. However, the fluorescence attributed to aniline blue was not uniform, and some portions of the cells were weakly or strongly stained after treatment with nagilactone $\mathrm{E}$ and a combination of both drugs. Strong fluorescence indicates the possibility of local $\beta$-glucan accumulation or perhaps extraordinary $\beta$-glucan biosynthesis. The localization of mannan in the nagilactone-E- and combination-treated cells was similar to that in the control cells. The inhibition of cell wall synthesis by such drugs possibly causes the decline in fluorescence. However, the effects of nagilactone $E$ and the drug combination on the inhibition of $\beta$-glucan synthesis could not be confirmed based on $\beta$-glucan staining with fluorescent reagents.

\subsection{Cell Surface Structure and Thickness of Cell Wall}

If the architecture of the yeast cell wall was affected by nagilactone E upon combinatorial treatment with drugs, visible damage could be detected on the cell surface or thinning of the cell wall could be observed. To observe the changes in the cell wall structure, especially at the surface, we performed quick-freeze deep-etch electron microscopy.

Exponentially growing cells were incubated with or without drugs and prepared for microscopy. The shapes of the cells visualized by electron microscopy were similar to those of living cells visualized by optical microscopy (Figure 6A). The fibrous structures were observed to be intricately intertwined on the cell surface (Figure 6A, surface), and the thickness of the cell wall was approximately $100 \mathrm{~nm}$ (Figure 6A, fractured). In the fractured surface image, a two-layered structure was observed on the cell surface with entangled fibers on the outer layer. The inner side had high-density packed materials (Figure 6A fractured). The surface of the cells treated with nagilactone E or anethole alone was filamentous, similar to that of control cells. However, a few fiber-like structures were observed on the surface of cells treated with the drug combination (Figure 6B). Namely, the surface was largely smooth; moreover, the outermost layer seemed to be peeled off. These results indicated that the drug combination affects the integrity of the outermost layer of the cell wall. The cell wall structure was maintained until $72 \mathrm{~h}$ after treatment with nagilactone $\mathrm{E}$ alone. 
A

B
은
음
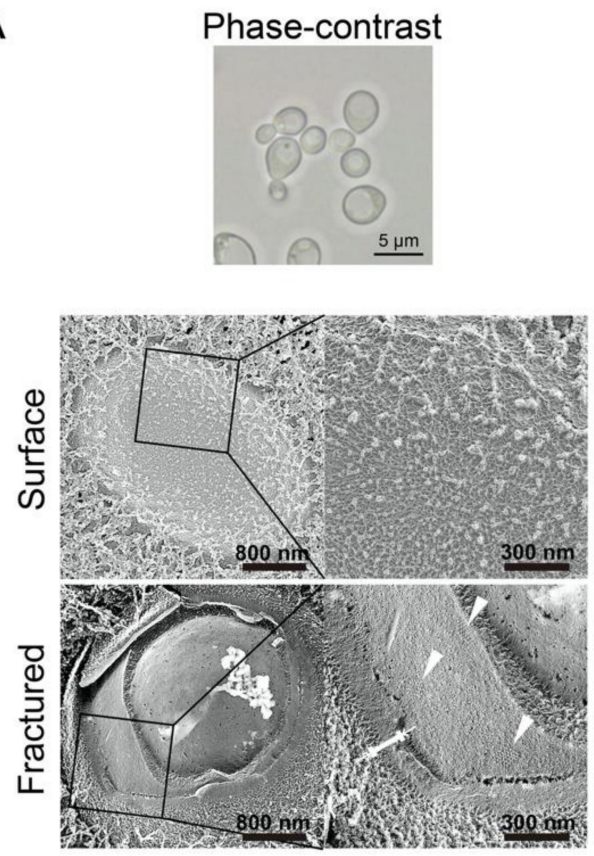

C
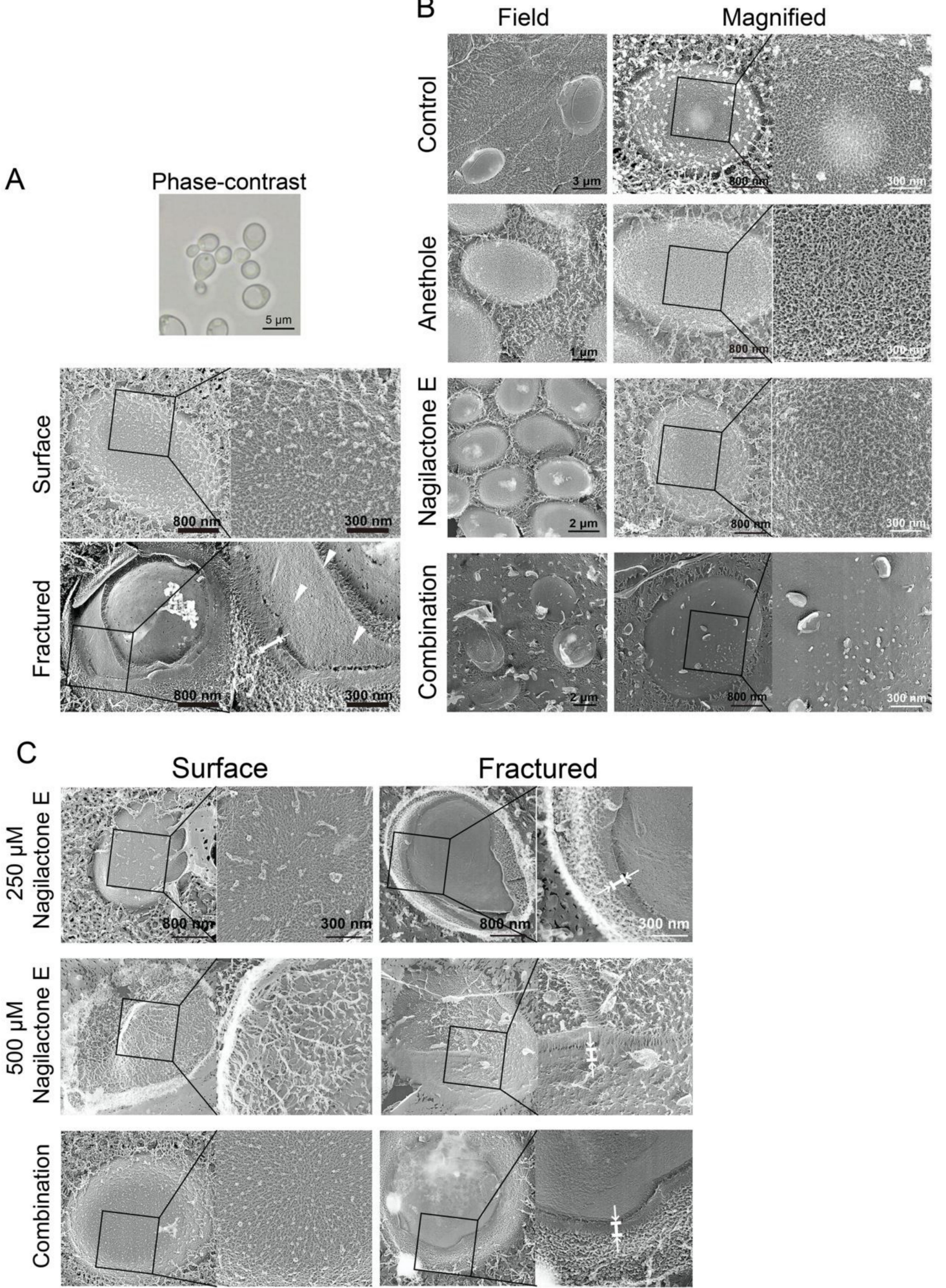

Figure 6. Quick-freeze deep-etch replica images of S. cerevisiae BY4741 cells. (A) The surface and fractured images of yeast cells (magnified). Exponentially growing cells without drug treatment were observed. (B) The surface of yeast cells in field and magnified images. Exponentially growing cells were grown at $30^{\circ} \mathrm{C}$ for $72 \mathrm{~h}$ in $2.5 \% \mathrm{ME}$ treated with $312.5 \mu \mathrm{M}$ anethole, $250 \mu \mathrm{M}$ nagilactone $\mathrm{E}$, or their combination. Control denotes treatment without drugs. (C) The surface and fractured images of yeast cells (magnified). Exponentially growing cells were grown at $30{ }^{\circ} \mathrm{C}$ for $48 \mathrm{~h}$ in $2.5 \% \mathrm{ME}$ treated with 250 and $500 \mu \mathrm{M}$ nagilactone $\mathrm{E}$ and $250 \mu \mathrm{M}$ nagilactone $\mathrm{E}$ combined with $312.5 \mu \mathrm{M}$ anethole (combination). 
The decrease in cell viability was the highest after $48 \mathrm{~h}$ of treatment with nagilactone E. Hence, we observed the cell surface after $48 \mathrm{~h}$ of treatment with nagilactone $\mathrm{E}$ or the drug combination. On the surface of cells treated with $500 \mu \mathrm{M}$ (twofold of MIC), the density and number of fibers were apparently reduced (Figure 6C); however, we did not find any differences in the structures present on the cell surface and in fractured surface images of cells treated with $250 \mu \mathrm{M}$ nagilactone $\mathrm{E}$ (MIC) or a combination of $250 \mu \mathrm{M}$ nagilactone $\mathrm{E}$ and $312 \mu \mathrm{M}$ anethole, similar to control cells.

We tested the effect of the $\beta$-glucan biosynthesis inhibitor, micafungin, on the cell surface structure. Prior to microscopic observation, the cells were incubated with $0.1 \sim 0.4 \mu \mathrm{M}$ micafungin for 24 or $48 \mathrm{~h}$. The MIC of micafungin was $0.2 \mu \mathrm{M}$ after $48 \mathrm{~h}$ incubation. As the concentration of micafungin increased, the filamentous structures on the cell surface gradually decreased and became rough at $0.4 \mu \mathrm{M}$ (Figure 7A). The density of fibers present on the cell surface after treatment with $0.4 \mu \mathrm{M}$ for $48 \mathrm{~h}$ was similar to that of fibers treated with $500 \mu \mathrm{M}$ nagilactone E. The tangled fibers with gaps were observed on the cell surface and were different from the cell surface of drug-combination-treated cells (Figure 6B). The cell walls of micafungin-treated cells were stained with aniline blue and FITC-ConA (Supplementary Figure S2E). This supported the results obtained by electron microscopy.

The cell wall of $S$. cerevisiae consists of three components: chitin, $\beta$-glucan, and mannoproteins. The content of chitin is lower than that of other components, except in the chitin ring, which is associated with septum formation during budding [22]. Among all the cell wall components, $\beta$-glucan and mannoproteins could not be visually distinguished on the basis of the cell surface characteristics observed in the electron micrographs. Therefore, we attempted to distinguish them by treating the cells with mannanase and/or proteinase K. After treatment, we stained the cells with FITC-ConA that targets mannan and mannoproteins. The cell walls of enzyme-treated cells were uniformly stained. Thus, we found no difference in the mannan content of the cells (Supplementary Figure S2C). Differences in the thickness of fibers were observed in cells treated with or without proteinase $\mathrm{K}$, whereas no significant differences were observed in mannanase-treated cells (Figure 8). The fibers present on the cell surface appeared white in the images. The ratio of the black to the white area was calculated after the conversion of monochrome binary images (Figure 9). In the images of the proteinase-K- and drug-combination-treated cells, the percentage of the black area was high. This observation indicated that the fibers, which appear as white areas, were reduced or became thin upon treatment. However, we could not distinguish between $\beta$-glucan and mannoproteins in the electron micrographs.

Finally, we observed the surface of spheroplast cells prepared by zymolyase treatment. Zymolyase contains protease, $\beta$-1,3-glucanase, and mannanase. The surface of zymolyasetreated cells was smooth, and few filamentous structures were observed (Figure 7B). Similar results were also obtained for drug-combination-treated cells (Figure 6B), wherein the cells contained reduced $\beta$-glucan and mannan content. Treatment with zymolyase might have caused a collapse of the cell wall, thereby entirely removing it. Therefore, the smooth surface observed in zymolyase-treated cells reflects the presence of residual cell wall components in the plasma membrane environment. In contrast, in the case of the drugcombination-treated cells, the smooth surface possibly reflects a lack of intertwined fibers in the outermost layer of the cell wall. 


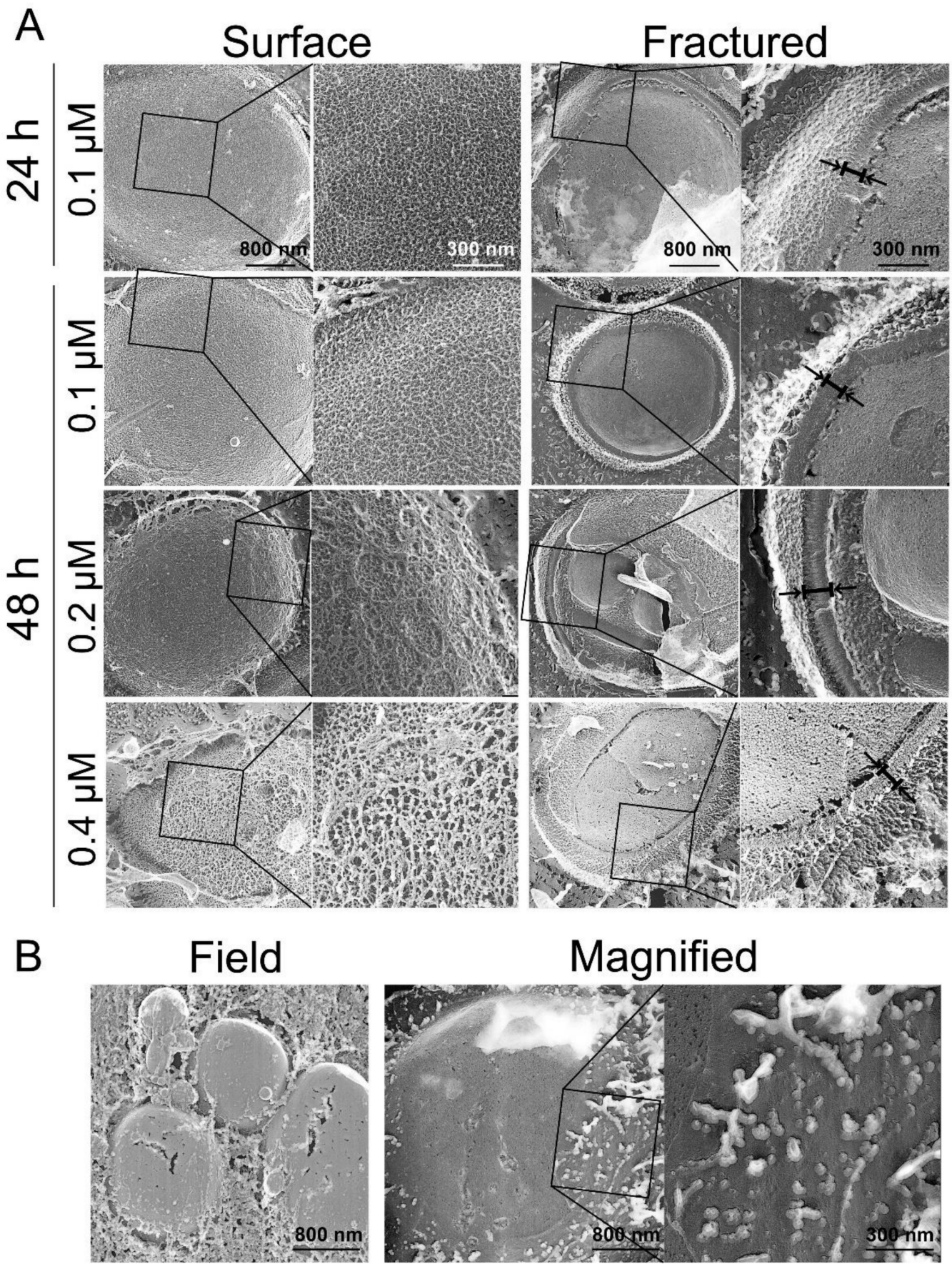

Figure 7. The surface and fractured images of micafungin- or zymolyase-treated yeast cells. (A) Exponentially growing cells were cultured in $2.5 \% \mathrm{ME}$ treated with micafungin at $30^{\circ} \mathrm{C}$. (B) Exponentially growing cells were treated with zymolyase $20 \mathrm{~T}$ at $30^{\circ} \mathrm{C}$ for $30 \mathrm{~min}$. 


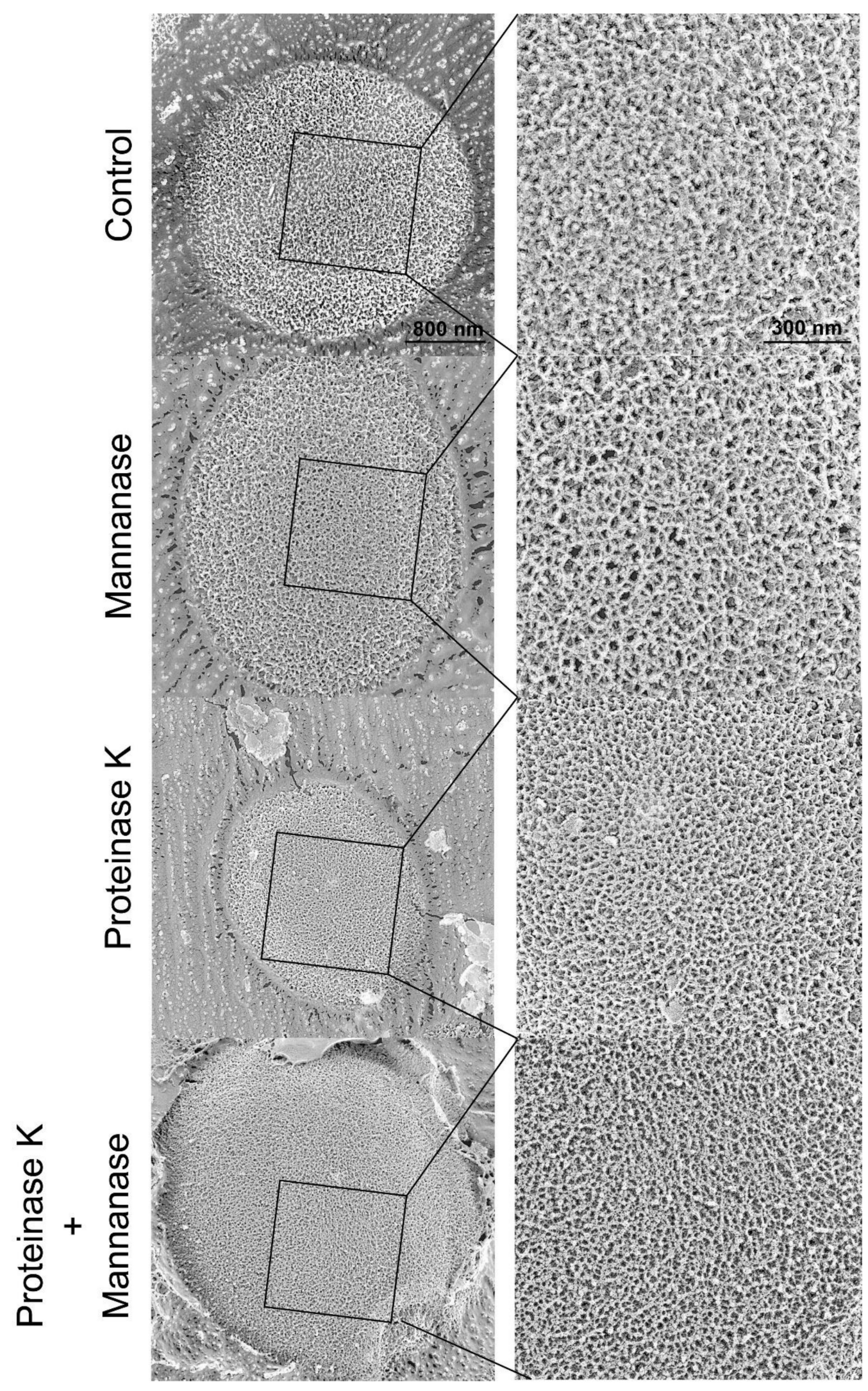

Figure 8. The surface of yeast cells treated with mannanase and/or proteinase $\mathrm{K}$ in field and magnified images. Exponentially growing cells were treated with mannanase and/or proteinase $\mathrm{K}$ at $37^{\circ} \mathrm{C}$ for $30 \mathrm{~min}$. 


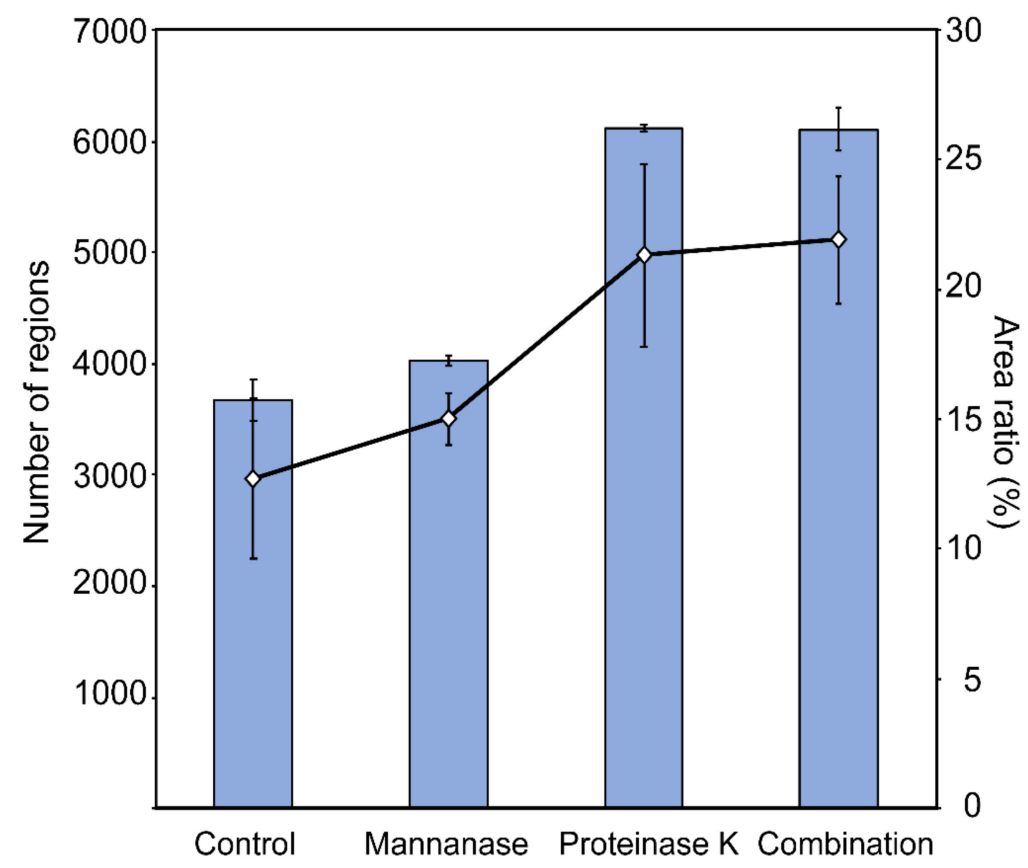

Figure 9. Quantification of the total dent area on the cell surface. The surface images in Figure 8 were converted to black-and-white binary. The number of black areas with an area of 100 pixels or more (bar chart) was counted, and the percentage of the area it occupies (line chart) was also calculated. The increase in the black area indicates an increase in the dent area on the cell surface. Data are expressed as the mean \pm standard deviation $(n=3)$.

\section{Discussion}

Nagilactone E exhibits antifungal activities against nonpathogenic $S$. cerevisiae and the human pathogen $C$. albicans by inhibiting $1,3-\beta$ glucan synthase and thereby affecting the fragility of the cell wall $[9,21]$. However, its activity is weaker than that of antifungal drugs present in the market. Therefore, the antifungal effect of nagilactone $\mathrm{E}$ in combination with other drugs needs to be checked, preferably with natural antifungal agents. Anethole is known to assist other drugs such as $n$-dodecanol and shows synergistic antifungal activity by inhibiting PDR5 transcription and affecting drug efflux pump activity [17]. In this study, we demonstrated the synergistic effects of nagilactone $E$ and anethole in combination and elucidated the underlying mechanism of their synergistic action.

The FIC indices (Table 1) and results of the time-kill assay (Figure 2) confirmed the synergistic effects of nagilactone $\mathrm{E}$ and anethole in combination. In addition, the strain lacking the PDR5 gene was more susceptible to nagilactone $\mathrm{E}$ than its parental strain (Figure 3). Nagilactone E increased PDR5 transcription and anethole suppressed PDR5 upregulation in the drug-combination-treated parental strain after $72 \mathrm{~h}$ (Figure 4). Fluorescence derived from GFP was intensely detected in nagilactone-E-treated cells but not in combination-treated cells (Figure 5). To summarize these results, nagilactone E induced Pdr5p overexpression. This could explain why the growth of nagilactone-E-treated cells recovered as incubation proceeded. In other words, anethole inhibits PDR5 transcription and maintains nagilactone E within cells. However, PDR5 transcription in combination-treated cells considerably increased at $4 \mathrm{~h}$ (Figure 4 ), and the reason behind this is currently unknown. The inhibition of the transcription may be potentiated as the increasing intracellular concentration of anethole. In addition, several transcription products were probably not translated; therefore, no fluorescence from GFP was observed in combination-treated cells. In addition, in nagilactone-E-treated cells, a time lag was observed between the increase in PDR5 transcription and increase in fluorescence intensity (Figures 4 and 5). Although constant levels of transcription were present, as measured by RT-qPCR, PDR 5 expression was checked after $72 \mathrm{~h}$ of incubation. Although the mechanisms of post-transcriptional 
regulation, such as increased translational efficiency of eukaryotes, have been reported previously [23-27], post-transcriptional regulation via mRNA degradation and other regulatory mechanisms of PDR5 are unclear. In the control cells, weak fluorescence was observed, even in the absence of transcription, and can be because of translation of all the residual transcription products. Therefore, protein levels and localization of Pdr5p are to be interpreted, and not the transcription level.

To visualize $\beta$-glucan in the cell wall of combination-treated cells, we stained the cells with aniline blue. No fluorescence was detected in zymolyase-treated spheroplasts, indicating the absence of $\beta$-glucan (Supplementary Figure S2B). Fluorescence along the perimeter of cells was detected without interruption in combination-treated and nagilactone-E-treated cells (Supplementary Figure S2A). The other major component, mannan, was examined in a similar way using FITC-ConA (Supplementary Figure S2D). The results indicated the presence of $\beta$-glucan and mannan tightly surrounding the cell walls. From these results, we could not confirm the apparent inhibition of cell wall $\beta$-glucan synthesis. As fluorescence intensity was related to the amount of the target mannan and $\beta$-glucan, the intensity did not indicate the strength of the cell wall.

Next, we analyzed the effects of nagilactone $E$ on the cell wall of drug-treated yeast cells using quick-freeze deep-etch electron microscopy. The cell wall consists of mannan and glucan, the primary components of the cell wall [21,28-31]. Under normal growth conditions, micrographs of the fractured surfaces revealed planes behind the cell wall, which were exposed by deep etching, and showed regions of aggregations of granular objects, possibly mannoproteins [32] (Figure 6A). The planes were considered to be the surface of the plasma membrane. In drug-combination-treated cells (Figure 6B), no fibers were observed on the cell surface, indicating an abnormal cell wall architecture, similar to the surface of the zymolyase-treated cells. The combination-treated cells showed aniline blue staining, whereas zymolyase-treated cells did not. The visible stained structures on the surface after treatment with a combination of drugs did not include the plasma membrane. Our results obtained using cells stained with FITC-ConA and aniline blue indicated that mannanase and/or proteinase $\mathrm{K}$ treatment cannot completely remove mannoproteins, unlike zymolyase treatment. However, no significant difference was observed in the electron micrographs. In contrast, similar fibrous structures of the outermost layer were observed in the vegetative cells of the fission yeast, Schizosaccharomyces pombe [33]. These fibers are known to consist of galactomannan in S. pombe [34]. This indicates that the fibers in the outermost layers of the $S$. cerevisiae cell wall are possibly mannan, as determined in previous reports $[35,36]$. Although small changes were detected on the cell surface by enzyme treatments including proteinase K (Figures 8 and 9), these changes could not lead us to conclude that the outermost layer of the cell wall only consisted of mannoproteins. Further investigations are needed to reveal the detailed structure of the cell wall of budding yeast, including the top surface fibers.

Contradictory results were obtained in aniline blue staining and electron microscopy. Although cell surface structures with a few fibers were observed in combination-treated and zymolyase-treated cells, the combination-treated cells showed aniline-blue-positive staining, whereas zymolyase-treated cells remained unstained. This could be explained by morphological differences observed in the cells based on the phase-contrast images (Supplementary Figure S2). Elliptical yeast forms were observed in combination-treated cells, and circular forms were observed in zymolyase-treated cells. The circular form probably indicates a complete loss of the cell wall. The ellipse form indicates the presence of residual cell wall components. This difference in morphology and the results of electron microscopy collectively indicated that the cells treated with the drug combination were not spheroplasts; however, the cell wall underwent significant alterations upon treatment.

Although nagilactones are known to be plant growth inhibitors, nagilactone E only inhibits fungi. Various phenylpropanoids, including anethole, probably enhance the antifungal activity of nagilactone $\mathrm{E}$ against $S$. cerevisiae, C. albicans, and $P$. ovale. In combination with anethole, nagilactone E exhibits a synergistic effect. As a result, the cell walls became 
brittle. The drug combination induced cell lysis under low osmotic conditions such as malt extract (ME) medium, and then anethole potentiated the activity of nagilactone E. Synergistic effects are expected to be observed in cells treated with nagilactone $\mathrm{E}$ in combination with other phenylpropanoids, probably inducing the inhibition of drug efflux, similar to anethole.

Nagilactone E weakly inhibits $\beta$-glucan synthase in fungi [9] and is transported by the drug efflux pump. The antifungal activity of the drug is relatively weak; however, it can be used as an antifungal agent because of its selective action on fungi, including human pathogens C. albicans and Aspergillus spp., in addition to S. cerevisiae [37,38]. Furthermore, enhancing the weak antifungal activity of nagilactone E may help us to use it to restrict fungal food spoilage.

\section{Materials and Methods}

\subsection{Strains and Culture Conditions}

The parental strain S. cerevisiae BY4741 (MATa, ura3 $\Delta 0$, leu2 $\Delta 0$, met $15 \Delta 0$, and his $3 \Delta 1)$ and its derived knockout strains ( $p d r 1 \Delta /$ YGL013C, $p d r 3 \Delta /$ YBL005W, $p d r 5 \Delta / Y O R 153 W$, $p d r 8 \Delta /$ YLR266C, $p d r 10 \Delta /$ YOR328W, pdr11 $\Delta /$ YIL013C, pdr12 $\Delta /$ YPL058C, $p d r 15 \Delta /$ YDR406W, adp1 $\Delta /$ YCR011C, aus1 $\Delta /$ YOR011W, snq2 $\Delta$ /YDR011W, yrs1 $\Delta /$ YGR281W, and yrr1 $\Delta /$ YOR162C) were purchased from the Yeast Knockout Strain Collection (Thermo Scientific Open Biosystems, Waltham, MA, USA). S. cerevisiae dTC063 ( $p d r 1 \Delta, p d r 3 \Delta, p d r 5 \Delta, p d r 8 \Delta, p d r 10 \Delta, p d r 11 \Delta$, $p d r 12 \Delta, p d r 15 \Delta, a d p 1 \Delta$, aus $1 \Delta, s n q 2 \Delta, y r s 1 \Delta$, and yrr1 $\Delta$ ) was gifted by Prof. Usui Takeo, University of Tsukuba (Tsukuba, Japan). S. cerevisiae BY25929 (pdr1 $\Delta$ pdr3 3 ) was provided by the National BioResource Project -Yeast (Osaka, Japan). The parental strain C. albicans NBRC1061 (wild type) was obtained from the Biological Resource Center, National Institute of Technology and Evaluation (Tokyo, Japan). C. albicans IFM46910 and IFM54354 (fluconazole resistant) were provided by the Medical Mycology Research Center, Chiba University (Chiba, Japan). The yeast cells were grown in 2.5\% ME $(\mathrm{m} / \mathrm{v}$; Oriental Yeast, Tokyo, Japan) broth at $30^{\circ} \mathrm{C}$, unless otherwise stated.

\subsection{Chemicals}

Nagilactone E was taken from the laboratory stock [8]. trans-Anethole (anethole) was purchased from Sigma-Aldrich (St. Louis, MO, USA). Micafungin was gifted by Astellas Pharma Inc. (Tokyo, Japan). Zymolyase 20T was purchased from Nacalai Tesque (Kyoto, Japan). Mannanase was gifted by Amano Enzyme Inc. (Nagoya, Japan). FITCConA was purchased from Seikagaku Corporation (Tokyo, Japan). Aniline blue dye and DMF were purchased from Wako Pure Chemicals (Osaka, Japan). Proteinase K was purchased from Merck (Darmstadt, Germany). The drugs were dissolved in their respective solvents before starting the experiments. Nagilactone E, trans-anethole, and micafungin were dissolved in DMF. Aniline blue dye was dissolved in $2 \mathrm{mM}$ 4-(2-hydroxyethyl)-1piperazineethanesulfonic acid (HEPES, pH 7.6) containing $150 \mathrm{mM} \mathrm{NaCl}$ and $1.2 \mathrm{M}$ sorbitol. FITC-ConA was dissolved in phosphate-buffered saline (PBS) consisting of $1.4 \mathrm{M} \mathrm{NaCl}$, $200 \mathrm{mM} \mathrm{Na}_{2} \mathrm{HPO} \cdot 12 \mathrm{H}_{2} \mathrm{O}, 27 \mathrm{mM} \mathrm{KCl}$, and $15 \mathrm{mM} \mathrm{KH}_{2} \mathrm{PO}_{4}$.

\subsection{Antifungal Susceptibility Assay}

The antifungal susceptibility assay was performed, as previously described [39]. Serial twofold dilutions of antifungal drugs were prepared in DMF, and $30 \mu \mathrm{L}$ of the drug solution was added to $3 \mathrm{~mL}$ of yeast peptone dextrose (YPD) medium consisting of $1 \%$ Bacto-yeast extract (BD, Franklin Lakes, NJ, USA), 2\% Bacto-peptone (BD), and 2\% D-glucose in a test tube (diameter of $10 \mathrm{~mm}$ ). The exponentially growing yeast cells of $S$. cerevisiae BY4741 and C. albicans NBRC1061, IFM46910, and IFM54354, were inoculated in the medium at a final cell density of $1.0 \times 10^{6} \mathrm{CFU} \mathrm{mL}{ }^{-1}$. The cultures were incubated without shaking at $30^{\circ} \mathrm{C}$ for $72 \mathrm{~h}$. After incubation, the MIC was determined, which was defined as the lowest concentration of the test compound at which no visible yeast growth was detected. 


\subsection{Time-Kill Assay}

Exponentially growing cells $\left(1.0 \times 10^{6} \mathrm{CFU} \mathrm{\textrm {mL } ^ { - 1 } )}\right.$ of $S$. cerevisiae BY4741 were incubated without shaking at $30^{\circ} \mathrm{C}$ for $72 \mathrm{~h}$ in ME broth containing anethole, nagilactone $\mathrm{E}$, or their combination. Aliquots of cell suspensions were withdrawn, diluted, and spread on YPD agar medium. The viable cell count was determined based on the number of CFUs after incubation for $48 \mathrm{~h}$ at $30^{\circ} \mathrm{C}$.

\subsection{Measurement of Cell Turbidity in Gene Deletion Strains Related to Drug Efflux}

Exponentially growing yeast cells of each strain $\left(1.0 \times 10^{7} \mathrm{CFU} \mathrm{mL}{ }^{-1}\right)$ were incubated with shaking at $30{ }^{\circ} \mathrm{C}$ for $72 \mathrm{~h}$ in ME broth containing $250 \mu \mathrm{M}$ nagilactone E. After incubation, the absorbance, as a measure of cell turbidity, was measured using a UV-2450 spectrophotometer (Shimadzu, Kyoto, Japan) at wavelength of $600 \mathrm{~nm}$.

\subsection{RNA Extraction and RT- $q P C R$}

Total RNA was extracted from S. cerevisiae BY4741 cells using the RNeasy Mini Kit (Qiagen, Hilden, Germany) according to the manufacturer's instructions. Briefly, yeast cells treated with anethole, nagilactone $\mathrm{E}$, or their combination were harvested by centrifugation at $3700 \times \mathrm{g}$ for $10 \mathrm{~min}$ and then lysed using $6.2 \mathrm{mg} \mathrm{mL}^{-1}$ of zymolyase 20T. The RNA samples were purified using the columns provided in the kit and were then treated with DNase. The RNA samples were reverse-transcribed to generate complementary DNA using ReverTra Ace (Toyobo, Osaka, Japan). The CDS primer (5'AAGCAGTGGTAACAACGCAGAGATACTTTTTTTTTTTTTTTTTTTTTTTTTTTTTTVN-3') was used for the reverse transcription reaction. RT-qPCR was performed using SsoAdvanced Universal SYBR Green Supermix (Bio Rad, Hercules, CA, USA) with complementary DNA as a template using the CFX Connect Real-Time PCR Detection System (Bio Rad, Hercules, CA, USA). The qPCR reaction mixture $(20 \mu \mathrm{L})$ contained $10 \mu \mathrm{L}$ of $2 \times$ Supermix, $5 \mathrm{ng}$ of the template, and $5 \mathrm{pM}$ of each of forward and reverse primers. The cycling profile was $3 \mathrm{~min}$ at $95^{\circ} \mathrm{C}$, followed by 40 cycles of $10 \mathrm{~s}$ at $95^{\circ} \mathrm{C}$, and $30 \mathrm{~s}$ at $55^{\circ} \mathrm{C}$. The relative expression of PDR5 was normalized to that of the housekeeping gene, ACT1, as an internal positive control. The primers used in this study are listed in Table 2.

Table 2. Primers used for RT-qPCR.

\begin{tabular}{cc}
\hline Primer Name & Sequence $\mathbf{( 5}^{\prime} \mathbf{- 3}^{\prime} \mathbf{)}$ \\
\hline$A C T 1-\mathrm{F}$ & ATGGTCGGTATGGGTCAAAA \\
ACT1-R & AACCAGCGTAAATTGGAACG \\
PDR5-F & GTTGCCTAAACCCAGGTGAA \\
PDR5-R & GTTGCCTAAACCCAGGTGAA \\
\hline
\end{tabular}

\subsection{Visualization of GFP-Pdr5p Fusion Protein}

Yeast cells $\left(1.0 \times 10^{7} \mathrm{CFU} \mathrm{mL}{ }^{-1}\right)$ were incubated in ME broth with anethole, nagilactone $\mathrm{E}$ or their combination for $72 \mathrm{~h}$. Aliquots were collected at the indicated times and centrifuged at $6800 \times g$ at $25^{\circ} \mathrm{C}$ for $3 \mathrm{~min}$. The harvested cells were washed twice with PBS and observed under a BX51 microscope (Olympus, Tokyo, Japan). The excitation and emission wavelengths for fluorescence visualization were 488 and $507 \mathrm{~nm}$, respectively.

\subsection{Aniline Blue Staining}

Exponentially growing yeast cells $\left(1.0 \times 10^{7} \mathrm{CFU} \mathrm{mL}^{-1}\right)$ of S. cerevisiae BY4741 were incubated without shaking at $30^{\circ} \mathrm{C}$ for $72 \mathrm{~h}$ in ME broth with $1.2 \mathrm{M}$ sorbitol containing $250 \mu \mathrm{M}$ nagilactone $\mathrm{E}$ and/or $312.5 \mu \mathrm{M}$ anethole. After incubation, the cells were harvested by centrifugation, washed twice with $2 \mathrm{mM}$ HEPES buffer ( $\mathrm{pH}$ 7.6) containing $150 \mathrm{mM} \mathrm{NaCl}$ and 1.2 M sorbitol, and resuspended in a small amount of HEPES buffer, and then $0.5 \%$ aniline blue dye (1/10 amount) was added and the cells were allowed to stand for $5 \mathrm{~min}$. 
The cells were observed under a BX51 microscope (Olympus). The excitation and emission wavelengths for fluorescence visualization were 370 and $430 \mathrm{~nm}$, respectively.

\subsection{Creating Spheroplasts}

Exponentially growing yeast cells $\left(1.0 \times 10^{7} \mathrm{CFU} \mathrm{mL}{ }^{-1}\right)$ of S. cerevisiae BY4741 were incubated without shaking at $30^{\circ} \mathrm{C}$ for up to $4 \mathrm{~h}$ in ME broth containing $1.2 \mathrm{M}$ sorbitol. The cells were washed twice with HEPES containing $1.2 \mathrm{M}$ sorbitol and then lysed using $15.6 \mathrm{mg} \mathrm{mL}^{-1}$ of zymolyase $20 \mathrm{~T}$ at $30{ }^{\circ} \mathrm{C}$ for $30 \mathrm{~min}$ with shaking in HEPES. Next, $0.5 \%$ aniline blue was added, and the cells were observed under the microscope.

\subsection{Visualization of the Cell Wall Using FITC-ConA}

Exponentially growing yeast cells $\left(1.0 \times 10^{7} \mathrm{CFU} \mathrm{mL}{ }^{-1}\right)$ were incubated without shaking at $30^{\circ} \mathrm{C}$ for $4 \mathrm{~h}$ in ME broth with $1.2 \mathrm{M}$ sorbitol containing $250 \mu \mathrm{M}$ nagilactone $\mathrm{E}$ and/or $312.5 \mu \mathrm{M}$ anethole and then washed twice with PBS containing 1.2 M sorbitol. The cells were washed with PBS, stained with FITC-ConA for $30 \mathrm{~min}$, fixed with $4 \%$ formalin for $30 \mathrm{~min}$, and then observed under a BX51 microscope (Olympus). The excitation and emission wavelengths for fluorescence visualization were 495 and $514 \mathrm{~nm}$, respectively. The cells treated with $70 \mathrm{mg} \mathrm{mL}^{-1}$ of mannanase and/or $1 \mu \mathrm{L} \mathrm{mL}^{-1}$ of proteinase $\mathrm{K}$ were stained with FITC-ConA at $37^{\circ} \mathrm{C}$ for 30 min with shaking in PBS containing $1.2 \mathrm{M}$ sorbitol.

\subsection{Quick-Freeze Deep-Etch Replica Electron Microscopy}

Exponentially growing yeast cells $\left(1.0 \times 10^{6} \mathrm{CFU} \mathrm{mL}^{-1}\right)$ of S. cerevisiae BY4741 were incubated in ME broth containing testing compounds for the indicated time without shaking. The cells were washed twice with HEPES buffer and harvested by centrifugation. The cells were mixed with a slurry that included mica flakes, placed on a rabbit lung slab, and frozen using CryoPress (Valiant Instruments, St. Louis, MO, USA) that was cooled using liquid helium $[33,40]$. The slurry was used to retain the appropriate volume of water before freezing. The specimens were fractured and etched for $15 \mathrm{~min}$ at $-104{ }^{\circ} \mathrm{C}$ using a JFDV freeze-etching device (JEOL Ltd., Akishima, Japan). The exposed cells were rotaryshadowed using platinum at an angle of $20^{\circ}$ and a thickness of $2 \mathrm{~nm}$ and backed with carbon. The replicas were floated off on full-strength hydrofluoric acid, rinsed with water, cleaned with commercial bleach, rinsed with water, and kept on copper grids, as described. The replica specimens were observed using a JEM-1010 transmission electron microscope (TEM, JEOL, Tokyo, Japan) at $80 \mathrm{kV}$, equipped with a FastScan-F214 (T) charge-coupled device (CCD) camera (TVIPS, Gauting, Germany). The cells $\left(1.0 \times 10^{7} \mathrm{CFU} \mathrm{mL}^{-1}\right)$ were also treated with zymolyase 20T, mannanase, and/or proteinase $\mathrm{K}$ in $2 \mathrm{mM}$ HEPES buffer (pH 7.6) containing $150 \mathrm{mM} \mathrm{NaCl}$ and $1.2 \mathrm{M}$ sorbitol at $30^{\circ} \mathrm{C}$ (zymolyase $20 \mathrm{~T}$ ) or $37^{\circ} \mathrm{C}$ (mannanase or proteinase $\mathrm{K}$ ) for $30 \mathrm{~min}$ with shaking. After treatment with mannanase and/or proteinase $\mathrm{K}$, the cells were fixed with $4 \%$ formalin, washed twice with water, centrifuged, and analyzed, as described above.

\subsection{Image Analyses for Cell Surface Damage}

All the images obtained using TEM were inverted to black-and-white binary using ImageJ 1.51j8 software. All the images were processed with a filter of smooth command six times and then converted to monochrome binary using a threshold command at the maximum threshold value set to 120 in 256 gradations. The number and area of black particles with more than 100 pixels in the images were then analyzed. For each image, the number and area ratios of the black particles were calculated.

Supplementary Materials: The following are available online at https:/ / www.mdpi.com/article/ 10.3390/antibiotics10050537/s1, Figure S1: Phase-contrast and fluorescent micrographs of cells expressing Pdr5p tagged with green fluorescent protein, Figure S2: Visualization of $\beta$-glucan and mannan in yeast cells stained with aniline blue and FITC-ConA, respectively. 
Author Contributions: Y.U. and K.-i.F. conceived and supervised the study; Y.U., K.-i.F., A.O., T.T. and M.M. designed the experiments; Y.U. and Y.O.T. performed the genetic and biochemical characterizations and microscopic observations; and Y.U., A.O., Y.Y. and K.-i.F. wrote the manuscript. All authors have read and agreed to the published version of the manuscript.

Funding: This research was partly funded by the Japan Society for the Promotion of Science, Grantsin-Aid for Scientific Research (C) 16K08299 and 21K07029.

Data Availability Statement: The data presented in this study are available on request from the corresponding author.

Acknowledgments: We are grateful to K. Hayashi and I. Kubo for their preliminary research concerning antifungal activities of anethole, nagilactone $\mathrm{E}$, and their combination.

Conflicts of Interest: The authors declare no conflict of interest.

\section{References}

1. Borgers, M.; Degreef, H.; Cauwenbergh, G. Fungal infections of the skin: Infection process and antimycotic therapy. Curr. Drug Targets 2005, 6, 849-862. [CrossRef]

2. Hayashi, Y.; Sakan, T. Nagilactones, plant growth regulators with antiauxin-like activity, plant growth substances. In Proceedings of the 8th International Conference on Plant Growth Substances, Tokyo, Japan, 26 August-1 September 1974; pp. 525-532.

3. Kubo, I.; Matsumoto, T.; Klocke, J.A. Multichemical resistance of the conifer Podocarpus gracilior (Podocarpaceae) to insect attack. J. Chem. Ecol. 1984, 10, 547-559. [CrossRef] [PubMed]

4. Russell, G.B.; Fenemore, P.G.; Singh, P. Insect-control chemicals from plants. Nagilactone C, A toxic substance from the leaves of Podocarpus nivalis and P. hallii. Aust. J. Biol. Sci. 1972, 25, 1025-1030. [CrossRef] [PubMed]

5. Shrestha, K.; Banskota, A.H.; Kodata, S.; Shrivastava, S.P.; Strobel, G.; Gewali, M.B. An antiprolifelative norditerpene dilactone, nagilactone C, from Podocarpus nerifolius. Phytomedicine 2001, 8, 489-491. [CrossRef]

6. Hayashi, Y.; Matsumoto, T.; Tashiro, T. Antitumor activity of norditerpenoid dilactones in Podocarpus plants: Structure-activity relationship on in vitro cytotoxicity against Yoshida sarcoma. Gan 1979, 70, 365-369. [CrossRef] [PubMed]

7. Kubo, I.; Sutisna, M.; Tan, K.S. Effects of nagilactones on the growth of lettuce seedlings. Phytochemistry 1991, 30, 455-456. [CrossRef]

8. Kubo, I.; Himejima, M. Potentiation of antifungal activity of sesquiterpene dialdehydes against Candida albicans and two other fungi. Experientia 1992, 48, 1162-1164. [CrossRef] [PubMed]

9. Hayashi, K.; Yamaguchi, Y.; Ogita, A.; Tanaka, T.; Kubo, I.; Fujita, K. Effect of nagilactoneE on cell morphology and glucan biosynthesis in budding yeast Saccharomyces cerevisiae. Fitoterapia 2018, 128, 112-117. [CrossRef] [PubMed]

10. Frost, D.J.; Brandt, K.D.; Cugier, D.; Goldman, R. A whole-cell Candida albicans assay for the detection of inhibitors towards fungal cell wall synthesis and assembly. J. Antibiot. 1995, 48, 306-310. [CrossRef]

11. Hitokoto, H.; Morozumi, S.; Wauke, T.; Sakai, S.; Kurata, H. Inhibitory effects of spices on growth and toxin production of toxigenic fungi. Appl. Environ. Microbiol. 1980, 39, 818-822. [CrossRef]

12. Kosalec, I.; Pepeljnjak, S.; Kuštrak, D. Antifungal activity of fluid extract and essential oil from anise fruits (Pimpinella anisum L., Apiaceae). Acta Pharm. 2005, 55, 377-385.

13. Yutani, M.; Hashimoto, Y.; Ogita, A.; Kubo, I.; Tanaka, T.; Fujita, K.-I. Morphological changes of the filamentous fungus Mucor mucedo and inhibition of chitin synthase activity induced by anethole. Phytother. Res. 2011, 25, 1707-1713. [CrossRef]

14. Fujita, K.-I.; Tatsumi, M.; Ogita, A. Anethole induces apoptotic cell death accompanied by reactive oxygen species production and DNA fragmentation in Aspergillus fumigatus and Saccharomyces cerevisiae. FEBS J. 2014, 281, 1304-1313. [CrossRef] [PubMed]

15. Fujita, K.-I.; Fujita, T.; Kubo, I. Anethole, a potential antimicrobial synergist, converts a fungistatic dodecanol to a fungicidal agent. Phytother. Res. 2007, 21, 47-51. [CrossRef] [PubMed]

16. Kubo, A.; Kubo, I. Antimicrobial agents from Tanacetum balsamita. J. Nat. Prod. 1995, 58, 1565-1569. [CrossRef]

17. Fujita, K.-I.; Ishikura, T.; Jono, Y. Anethole potentiates dodecanol's fungicidal activity by reducing PDR5 expression in budding yeast. Biochim. Biophys. Acta Gen. Subj. 2017, 1861, 477-484. [CrossRef] [PubMed]

18. Oyama, M.; Tamaki, H.; Yamaguchi, Y.; Ogita, A.; Tanaka, T.; Fujita, K.-I. Deletion of the Golgi Ca ${ }^{2+}-$ ATPase PMR1 gene $^{2}$ potentiates antifungal effects of dodecanol that depend on intracellular $\mathrm{Ca}^{2+}$ accumulation in budding yeast. FEMS Yeast Res. 2020, 20. [CrossRef]

19. Mahé, Y.; Lemoine, Y.; Kuchler, K. The ATP binding cassette transporters Pdr5 and Snq2 of Saccharomyces cerevisiae can mediate transport of steroids in vivo. J. Biol. Chem. 1998, 271, 25167-25172. [CrossRef] [PubMed]

20. Katzmann, D.J.; Burnett, P.E.; Golin, J.; Mahé, Y.; Moye-Rowley, W.S. Transcriptional control of the yeast PDR5 gene by the PDR3 gene product. Mol. Cel. Biol. 1994, 14, 4653-4661. [CrossRef] [PubMed]

21. Lipke, P.N.; Ovalle, R. Cell wall architecture in yeast: New structure and new challenges. J. Bacteriol. 1998, 180, 3735-3740. [CrossRef]

22. Klis, F.M.; Mol, P.; Hellingwerf, K.; Brul, S. Dynamics of cell wall structure in Saccharomyces cerevisiae. FEMS Microbiol. Rev. 2002, 26, 239-256. [CrossRef] [PubMed] 
23. Beyer, A.; Hollunder, J.; Nasheuer, H.P.; Wilhelm, T. Post-transcriptional expression regulation in the yeast Saccharomyces cerevisiae on a genomic scale. Mol. Cel. Proteom. 2004, 3, 1083-1092. [CrossRef]

24. GoncËalves, E.; Nakic, R.Z.; Zampieri, M.; Wagih, O.; Ochoa, D.; Sauer, U.; Beltrao, P.; Saez-Rodriguez, J. Systematic analysis of transcriptional and post-transcriptional regulation of metabolism in yeast. PLoS Comput. Biol. 2017, 13, e1005297. [CrossRef]

25. Hong, K.A.; Lee, S.H.; Gu, S.; Kim, E.; An, S.; Kwon, J.; Lee, J.-B.; Jang, S.K. The bent conformation of poly(A)-binding protein induced by RNA-binding is required for its translational activation function. RNA Biol. 2017, 14, 370-377. [CrossRef]

26. Preiss, T.; Muckenthaler, M.; Hentze, M.W. Poly-(A)-tail-promoted translation in yeast: Implications for translational control. RNA 1998, 4, 1321-1331. [CrossRef] [PubMed]

27. Tarun, S.Z., Jr.; Sachs, A.B. Association of the yeast poly(A) tail binding protein with translation initiation factor eIF-4G. EMBO J. 1996, 15, 7168-7177. [CrossRef] [PubMed]

28. Aguilar-Uscanga, B.; François, J.M. A study of the yeast cell wall composition and structure in response to growth conditions and mode of cultivation. Lett. Appl. Microbiol. 2003, 37, 268-274. [CrossRef]

29. Koehler, J.K.; Birnbaum, W., Jr.; Hayes, T.L. Electron microscope observations on Saccharomyces cerevisiae. Cytologia 1960, 26, 301-308. [CrossRef]

30. Osumi, M. Visualization of yeast cells by electron microscopy. J. Electron. Microsc. 2012, 61, 343-365. [CrossRef] [PubMed]

31. Smits, G.J.; Kapteyn, J.C.; Van Den Ende, H.; Klis, F.M. Cell wall dynamics in yeast. Curr. Opin. Microbiol. 1999, 2, 348-352. [CrossRef]

32. Klis, F.M.; Sosinska, G.J.; Groot, P.W.J.; Brul, S. Covalently linked cell wall proteins of Candida albicans and their role in fitness and virulence. FEMS Yeast Res. 2009, 9, 1013-1028. [CrossRef] [PubMed]

33. Tahara, O.Y.; Miyata, M.; Nakamura, T. Quick-freeze, deep-etch electron microscopy reveals the characteristic architecture of the fission yeast spore. J. Fungi 2021, 7, 7. [CrossRef]

34. Pérez, P.; Cortés, C.G.J.; Cansado, J.; Ribas, C.J. Fission yeast cell wall biosynthesis and cell integrity signalling. Cell Surf. 2018, 4, 1-9. [CrossRef] [PubMed]

35. Ene, I.V.; Walker, L.A.; Schiavone, M.; Lee, K.K.; Martin-Yken, H.; Dague, E.; Gow, N.A.R.; Munro, C.A.; Brown, A.J.P. Cell wall remodeling enzymes modulate fungal cell wall elasticity and osmotic stress resistance. mBio 2015, 6, e00986-15. [CrossRef]

36. Gonzalez, M.; Lipke, P.N.; Ovalle, R. GPI proteins in biogenesis and structure of yeast cell walls. Enzymes 2009, XXVI, 321-356. [CrossRef]

37. Denning, D.W. Echinocandin antifungal drugs. Lancet 2003, 362, 1142-1151. [CrossRef]

38. Kang, T.H.; Hwang, E.I.; Yun, B.S.; Park, K.D.; Kwon, B.M.; Shin, C.S.; Kim, S.U. Inhibition of chitin synthases and antifungal activities by 2'-benzoyloxycinnamaldehyde from Pleuropterus ciliinervis and its derivatives. Biol. Pharm. Bull. 2007, 30, 598-602. [CrossRef] [PubMed]

39. Fujita, K.-I.; Kubo, I. Antifungal activity of octyl gallate. Int. J. Food Microbiol. 2002, 79, 193-201. [CrossRef]

40. Tulum, I.; Tahara, Y.O.; Miyata, M. Peptidoglycan layer and disruption processes in Bacillus subtilis cells visualized using quick-freeze, deep-etch electron microscopy. Microscopy 2019, 68, 441-449. [CrossRef] [PubMed] 